\title{
DOES FINANCIAL SECRECY AFFECT PROFIT SHIFTING?
}

\author{
I Wayan Agus Eka
}

Direktorat Jenderal Pajak.Email: wayanaguseka@gmail.com

\begin{abstract}
Global efforts to increase financial transparency have been made throughout the last decade. Nevertheless, profit shifting among Multinational Companies still become a crucial issue worldwide. This study investigated whether financial secrecy is one of the determinants of profit shifting that has been overlooked in previous profit shifting studies. Using multiple regression analysis, I concluded that financial secrecy negatively affects profit shifting, meaning an increased transparency will induce taxpayers to shift profit out of the country since ending secrecy equals higher risk for the tax evaders. The finding implies two important recommendations: first, to continue the global efforts to promote financial information exchange for tax purposes and second, to strengthen domestic anti-profit shifting regulations.
\end{abstract}

Keywords: financial secrecy, financial transparency, banking secrecy, profit shifting, exchange of information.

\section{ABSTRAK}

Inisiatif global untuk meningkatkan transparansi telah dilakukan dalam satu dekade belakangan ini. Di sisi lain, pengalihan laba oleh perusahaan multinasional tetap menjadi isu penting. Penelitian ini menginvestigasi apakah kerahasiaan data keuangan merupakan salah satu variabel determinan dari pengalihan laba yang selama ini belum pernah diperhitungkan dalam penelitian-penelitian sebelumnya. Menggunakan analisis regresi berganda, penelitian ini menyimpulkan bahwa kerahasiaan data keuangan secara negatif memengaruhi pengalihan laba, yang berarti bahwa peningkatan transparansi memberikan insentif kepada Wajib Pajak untuk mengalihkan laba ke luar suatu negara karena peningkatan risiko yang dialami para Wajib Pajak. Penelitian ini menghasilkan dua rekomendasi: pertama, usaha untuk mewujudkan pertukaran informasi keuangan secara menyeluruh harus tetap dilanjutkan dan kedua, diperlukan penguatan peraturan untuk mencegah dan mengatasi pengalihan laba. 


\section{INTRODUCTION}

Over the last decade, taxation has become a major issue for top political leaders. They have started to realize the importance of raising tax revenue to finance sustainable developments. Taxation has also become a mandatory agenda in global economic forums in the midst of economic uncertainty and trade wars.

Since tax revenue has become the major revenue source after the declining of commodities prices, every nation has an interest to protect its tax base. It is not an easy job since 30\% of the international transactions involve affiliated multinational corporations (MNCs) that raise the concern of profit shifting (United Nation, 2017). G20/OECD countries then took an initiative to curb the base erosion and profit shifting known as BEPS Action Plan (OECD, 2015).

There is no precise number of how much the tax revenue is lost to profit shifting. OECD estimated the revenue loss at 4\%-10\% of the corporate tax revenue or USD100-240billion at 2014 levels (OECD, 2015a). Among all countries, non-OECD countries (which are commonly developing countries) bear more costs from profit shifting than developed countries (Crivelli, de Mooij \& Keen, 2015). Clausing (2016) estimated that profit shifting is costing roughly between $\$ 77$ billion to $\$ 111$ billion of 2012 US tax revenue. Furthermore, the most recent research from Torslov, Wier, and Zucman (2018) estimated that $40 \%$ of MNCs profits are shifted to low-tax countries each year.
A better understanding of profit shifting cannot be separated from the study of tax havens. One of its characteristics is financial secrecy. Jansky and Prats (2015) argued that there are two main reasons why tax havens play an important role in profit shifting: (i) low or nil tax rate and (ii) secrecy provision (banking secrecy, lack of exchange of tax information, etc.). Johannesen and Zucman (2014) also found that the end of Swiss bank secrecy through a tax treaty amendment with France results in a roughly $11 \%$ decline in the Swiss deposits held by French residents. OECD (1998) report emphasizes that defining tax haven is not only from a tax perspective, but also stress on the lack of exchange of information and transparency.

Tax haven, offshore financial center and secrecy jurisdiction are usually used interchangeably to describe a country that induces profit shifting. However, the unclear and disagreement on tax haven and offshore financial center definition contributed to the weakness in analyses (Cobham, Jansky \& Meinzer, 2015). The last term, secrecy jurisdiction, was promoted by Murphy (2008). He defined the secrecy jurisdiction as a jurisdiction which provides facilities that enable people or entities escape or undermine the laws, rules and regulations of other jurisdictions elsewhere, using secrecy as a prime tool (Murphy, 2008).

In connection with profit shifting, there are relatively more studies that use tax haven and offshore financial center terms than secrecy jurisdiction. Two notable studies, Hines and Rice (1994) and Johannesen and Zucman (2014), study how tax haven affect US firms' foreign activities. 
By contrast, several other research explores the roles of offshore financial center (Picard \& Pieretti, 2011; Foad \& Lundberg, 2017; Chernykh \& Mityakov, 2017).

Empirical studies on profit shifting mostly concentrated on how the profit shifting was affected by tax rate differential, commonly called as the semi-elasticity of profit shifting. Hines and Rice (1994), the pioneers of this study, estimated the semi-elasticity of 2.3, meaning a reduction in the tax rate by one percentage point will increase the reported profit by $2.3 \%$. Dozens of similar studies then followed Hines and Rice. In the latest study by Beer, de Mooij and Liu (2018) who reviewed all of these empirical studies, it was found that one percentage point reduction in the tax rate increases the before tax profit by $1.5 \%$.

In addition to the aforementioned, empirical research studying the connection between financial secrecy and profit shifting is still not well-developed in the literature. The study by Akhtar, Akhtar, John and Wong (2017) might be the closest one, as they investigated whether corporate governance affects the probability of tax evasion. This paper tries to fill the gap in the literature by empirically studying the impact of the financial secrecy on profit shifting. This paper also contributes to the literature since it tries to extend the determinants of profit shifting by including secrecy issue that was overlooked in the previous research.

\section{LITERATURE REVIEW}

\subsection{Profit Shifting}

There are several definitions of profit shifting. OECD (2018) defines profit shifting as allocation of income and expenses between related corporations or branches of the same legal entity (e.g., by using transfer pricing) in order to reduce the overall tax liability of the group or corporation. Similar objective is expressed by Huizinga and Laeven (2008) where profit shifting should reduce MNC profits reported in high-tax countries.

There are two main ways to shift profit: transfer pricing and financing structure (Maffini \& Mokkas, 2011; Buettner, Overesch \& Wamser, 2017). Another way involves treaty shopping and strategic location of intellectual property (Beer et al., 2018).

Transfer pricing is a neutral term. It is defined as a price set by a taxpayer when selling to, buying from, or sharing resource with a related person (Arnold \& Mclntyre, 2002). To minimize taxable profit, MNCs locating in high-tax country will overstate the import price and/or understate its export price (Huizinga \& Laeven, 2008). Moreover, transfer pricing is considered the dominant profit shifting channel based on meta-database analysis from 27 empirical studies (Heckemeyer \& Overesch, 2017).

In the context of financing structure, reducing tax burden can be achieved by imposing high interest rate to affiliated company located in high tax country (Huizinga \& Laeven, 2008). The main reason is that interest is deductible meanwhile dividends are not deductible hence 
debt financing is considered more effective than equity financing (Arnold \& Mclntyre, 2002).

\subsection{Determinant of Profit Shifting}

Most of the empirical research in profit shifting regards tax rate as the main profit shifting determinant since the potential tax savings rely on the difference in the corporate tax rate. Grubert and Mutti (1991) and Hines and Rice (1994) are considered the pioneers in empirical profit shifting study. Their papers used cross-sectional regression analysis for 1982 country-level data, resulted in similar finding that tax negatively affects reported profit; indicating the existence of profit shifting.

Another well-cited profit shifting literature was written by Huizinga and Laeven (2008) which extended Hines and Rice (1994) work. For the tax variable, Huizinga and Laeven (2008) build a composite index consisting not only the tax rate difference, but also other incentives to shift the profit. Unlike Hines and Rice (1994), Huizinga and Laeven used micro level data (company-level data) for the year 1999. The finding, however, was relatively consistent with previous study in that an increase in tax incentive (the tax rate difference) will significantly increase the profit shifting.

Another study that uses company-level data was carried out by Dharmapala and Riedel (2013). This paper did not only offer new way to measure profit shifting, but also used firm level panel data, enabling the author to control firm-level characteristic and year fixed effect. Dharmapala and Riedel (2013) found that parents' positive earning shocks are associated with a significantly positive increase in pretax profits at low-tax affiliates, relative to the effect on the pretax profits of high-tax affiliates. In addition to the tax differential as one of the main important variables, the study about profit shifting cannot be separated from the existence of tax havens. In principle, tax haven is a location with a very low tax rate and other tax-favorable characteristics to attract foreign direct investment (Dharmapala \& Hines, 2009). Dyreng and Lindsey (2009) studied how tax haven affect tax burden of US multinationals. They found that tax burden of US firms with tax haven operation was 1.5 percentage point lower than other firms.

In relation to tax haven, several other studies found that low-tax was not the only factor contributing to the existence of tax haven. Mara (2015) found that tax havens are associated with countries which GDPs are significantly made up of services. Hansen and Kessler (2001) studied the link between tax haven and geographical factors. They argued that small countries have a possibility to become tax havens since the land market could separate between wealthy and poor individuals due to limitation of land.

Perhaps the most widely cited literature on non-tax characteristics of tax haven is a study conducted by Dharmapala and Hines (2009). They focus on studying tax haven characteristics other than the tax rate using the cross-sectional data for the year 2004. The study used the tax haven list defined by Hines and Rice (1994). For the explanatory variable, the paper used the country-level governance 
index constructed by Kaufmann, Kraay, and Mastruzzi (2005). Other independent variables include GDP per capita, population, openness variable, and other geographical variables. The paper found that tax havens are small countries with high-quality governance. The finding also explains why low-level governance countries will never be a tax haven.

\subsection{Secrecy and Profit Shifting}

In addition to tax haven, literatures also commonly used two similar terms: offshore financial center and secrecy jurisdiction. While tax haven determination is closely connected with country with no or nominal tax (OECD, 1998), offshore financial center is indicated by provision of intermediation services for larger neighboring countries (Rose \& Siegel, 2007). Secrecy jurisdiction, on the other hand, relates to the legislative provision of financial secrecy to those who are physically resident elsewhere (Cobham, Jansky \& Meinzer, 2015). Even though those terms provide different emphases, they offer similar characteristic: financial secrecy. The level of secrecy in the financial institution of a particular jurisdiction is one of the main properties of tax haven, offshore financial center as well as secrecy jurisdiction. Therefore, this paper will use financial secrecy as the main variable of interest.

Literature that discussed the direct connection between financial secrecy and profit shifting is limited. Most of them examined financial secrecy (or governance index) in connection with tax haven. Dharmapala and Hines (2009) study the components that makes up a tax haven. As the dependent variable, they used the tax haven list defined by Hines and Rice (1994). For independent variables, they used both economic indicators such as the GDP per capita and geographical indicators such as population and area. With regard to transparency in this paper, Dharmapala and Hines (2009) used the governance index from Kaufmann et al. (2005). The governance index is constructed from six different elements: voice and accountability, political stability, government effectiveness, regulatory quality, rule of law, and control of corruption. Using cross-sectional regression, the study shows that the level of governance has a positive and significant impact on the probability of being a tax haven.

Akhtar et al. (2017) study whether governance level contributes to the likelihood of MNCs committing tax evasion. The use of the governance variable (both micro and country level) in Akhtar et al. (2017), to some extent, is similar to this study that uses financial secrecy as a variable of interest. In addition, Akhtar et al. (2017) investigate if the probability of conducting tax evasion was caused by the level of governance. This purpose is somewhat similar to this paper, which tries to study the level of financial secrecy as one of the profit shifting determinants.

Low-level of financial secrecy means that the tax authority in that jurisdiction has a relatively higher access to financial data compared to those in jurisdictions with high-level financial secrecy. 
That is why I presume that MNCs located in jurisdictions with low-level of financial secrecy have the incentive to shift their profit to other jurisdictions with higher level of secrecy.

\section{DATA AND METHODOLOGY}

Empirical research in profit shifting usually uses the accounting-based profit as the dependent variable. Hines and Rice (1994) used the pre-tax non-financial income meanwhile Huizinga and Laeven (2008) used the earnings before interest and tax as the dependent variable. This paper, however, will use the illicit financial outflows data provided by Global Financial Integrity. The main reason is that the illicit financial outflows data was constructed primarily based on trade misinvoicing (Global Financial Integrity, 2017). Therefore, I argue that the illicit financial outflows data is able to become a proxy for profit shifting since fraudulent misinvoicing is the main tool in transfer pricing abuse.

The main purpose of this paper is to study empirically whether the level of transparency induces profit shifting. Transparency is the common characteristic that can be found in three following terms: tax haven, offshore financial center, and secrecy jurisdiction. As an indicator of transparency, I use secrecy score provided by Tax Justice Network. Secrecy score ranges from 0 to 100. High score means that the jurisdiction lacks transparency, is unwilling to engage in information exchange and is less compliant with international norm to combat money-laundering
(Tax Justice Network, 2015). Conversely, low score means that the jurisdiction is more transparent and there is a higher compliance in information exchange.

The secrecy score is a qualitative measure looking at a jurisdiction's laws and regulation, international treaties and so on. It was constructed based on 15 key financial secrecy indicators. Among these indicators, several important ones are related to bank secrecy, country-by-country reporting, tax administration efficiency, tax treaty, and automatic exchange of information (Tax Justice Network, 2015). Therefore, secrecy score should be able to represent the level of transparency of a particular jurisdiction.

The control variables used in this analysis include, among others, the logs of GDP per capita obtained from the World Bank's World Development Indicators database. This variable is also used by Baumann, Buchwald, Friehe, Hottenrott and Weche (2016). This paper also controls countries governance institution represented by the Government Effectiveness Index provided by The Worldwide Governance Indicators. The Government Effectiveness Index reflects the perceptions of the quality of public services, the quality of the civil service and the degree of its independence from political pressures, the quality of policy formulation and implementation, and the credibility of the government's commitment to such policies. The index takes values from -2.5 to 2.5 , in which higher value indicates better effectiveness.

This paper also aims to provide information about the semi-elasticity of tax rate to profit shifting. Therefore, I also include tax rate as one of the control 
variables. The tax rate data is provided by KPMG.

I also include two country characteristic variables: development/high income and tax haven status. I use the binary variable representing developed (value as 1) and developing countries (value as 0). Countries categorized as high-income countries based on The World Bank classification are considered developed countries. From this binary variable, I would like to know whether there is significant difference in profit shifting between those high-income and non-high-income countries.

It is also interesting to know whether profit shifting is different between tax haven and non-tax haven countries. Therefore, I also include the binary variable representing the tax haven status. The list of tax haven countries is obtained from Dyreng and Lindsey (2009).

The baseline econometric specification is summarized by:

$$
\begin{aligned}
& \text { liffo }_{i t}=\beta_{0}+\beta_{1} s s_{i t}+\beta_{2} \text { lgpdpc }_{i t} \\
& +\beta_{3} \text { goveff }_{i t}+\beta_{4} \text { taxrate }_{i t} \\
& +\beta_{5} \text { high }_{i t}+\beta_{6} \text { nonhaven }_{i t} \\
& +\varepsilon_{i t}
\end{aligned}
$$

Definitions of the variables as well as summary of the datal sources can be seen in the Appendix. The secrecy score variable (ss), as the main variable of interest, is based on report issued by Tax Justice Network in 2011, 2012 and 2014. However, the data for the report were based on the observations for the year before. Therefore, the year coverage in this paper is 3 years: 2010, 2012 and 2014.
Robustness Check

For robustness check I changed two variables in the baseline specification. First, for dependent variable I used the amount of illicit outflow from trade misinvoicing data provided by Global Financial Integrity. This variable measures the fraudulent manipulation of the price, quantity, or quality of a good or service on an invoice allowing tax evaders to shift profit across international borders (Global Financial Integrity, 2017). Second, I replaced the government effectiveness to government quality index provided by The Worldwide Governance Indicators. The government quality index reflects the perceptions of the ability of the government to formulate and implement sound policies and regulations that permit and promote private sector developments.

The robustness check specification is summarized by:

$$
\begin{aligned}
& \text { ltmo }_{i t}=\beta_{0}+\beta_{1} s s_{i t}+\beta_{2} \text { lgpdpc }_{i t} \\
& +\beta_{3} \text { govqual }_{i t}+\beta_{4} \text { taxrate }_{i t} \\
& +\beta_{5} \text { high }_{i t}+\beta_{6} \text { nonhaven }_{i t}+\varepsilon_{i t}
\end{aligned}
$$


Summary statistics is shown in Table 1 and the variables descriptions as well as the data source is provided in the Appendix.

Table 1 Summary Statistics Source: Stata Output

\begin{tabular}{lcrrrrrrr}
\hline \multicolumn{1}{c}{ Variable } & N & \multicolumn{1}{c}{ Mean } & \multicolumn{1}{c}{ Std. Dev } & \multicolumn{1}{c}{ Min } & \multicolumn{1}{c}{ Q1 } & Median & Q2 \\
\hline Illicit Financial Flows Outflow (Million of US\$) & \multicolumn{1}{c}{369} & $4,860.28$ & $16,875.93$ & 1.00 & 128.00 & 621.00 & $3,142.00$ & $192,372.00$ \\
Trade Misinvoicing Outflow (Million of US\$) & 332 & $3,524.02$ & $10,464.45$ & 1.00 & 88.00 & 446.50 & $2,243.50$ & $84,115.00$ \\
Secrecy Score & 231 & 65.24 & 16.19 & 31.00 & 52.00 & 70.00 & 78.91 & 93.31 \\
GDP per Capita (Current US\$) & 605 & $16,049.95$ & $23,485.87$ & 231.19 & $1,928.96$ & $6,231.77$ & $19,729.87$ & $179,308.10$ \\
Government Effectiveness & 593 & -0.01 & 0.99 & -2.45 & -0.76 & -0.11 & 0.74 & 2.24 \\
Government Quality & 593 & -0.02 & 1.00 & -2.53 & -0.76 & -0.12 & 0.66 & 2.23 \\
Tax Rate (\%) & 495 & 17.38 & 12.91 & 0.00 & 0.00 & 20.00 & 28.00 & 55.00 \\
Developed Country (=1) & 654 & 0.37 & 0.48 & 0.00 & 0.00 & 0.00 & 1.00 & 1.00 \\
Non Haven Country (=1) & 654 & 0.79 & 0.41 & 0.00 & 1.00 & 1.00 & 1.00 & 1.00 \\
\hline
\end{tabular}

\section{RESULT AND DISCUSSION}

\subsection{Variable of Interest}

Table 2 provides the regression results in three variations. The first column shows the most basic regression equation including only the secrecy score as the independent variable and the illicit financial outflow as the dependent variable. Column 2 is the main regression results adding all of the control variables. The last column basically runs the same thing as the second column with only the addition for an interaction variable between the development status and the tax haven status.

Regression 1 shows that the transparency level has a negative significant impact on profit shifting. After controlling several variables, regression 2 basically shows similar result in which transparency level moved in opposite direction of the profit shifting (in 10\% significance level).

\begin{tabular}{|c|c|c|c|}
\hline & (1) & (2) & (3) \\
\hline VARIABLES & liffo & liffo & liffo \\
\hline \multirow[t]{2}{*}{ ss } & $-0.119^{\star \star \star}$ & $-0.0326^{\star}$ & $-0.0461^{* * *}$ \\
\hline & $(0.0126)$ & $(0.0165)$ & $(0.0172)$ \\
\hline \multirow[t]{2}{*}{ Igdppc } & & $1.365^{\star \star \star}$ & $1.288^{\star * *}$ \\
\hline & & $(0.352)$ & $(0.348)$ \\
\hline \multirow[t]{2}{*}{ goveff } & & -0.191 & -0.0901 \\
\hline & & $(0.439)$ & $(0.458)$ \\
\hline \multirow[t]{2}{*}{ taxrate } & & $0.0660^{\star \star \star}$ & $0.0593^{\star \star \star}$ \\
\hline & & $(0.0212)$ & $(0.0223)$ \\
\hline \multirow[t]{2}{*}{ high } & & $-1.077^{* *}$ & -0.775 \\
\hline & & $(0.519)$ & $(0.612)$ \\
\hline \multirow[t]{2}{*}{ nonhaven } & & $2.401^{\star \star \star}$ & $2.537^{\star \star \star}$ \\
\hline & & $(0.6)$ & $(0.634)$ \\
\hline \multirow[t]{2}{*}{ high_nonhaven } & & & $-1.332^{*}$ \\
\hline & & & $(0.776)$ \\
\hline \multirow[t]{2}{*}{ Constant } & $15.04^{\star \star *}$ & -4.975 & -3.317 \\
\hline & $(0.922)$ & (3.276) & (3.305) \\
\hline Observations & 89 & 76 & 76 \\
\hline R-squared & 0.403 & 0.628 & 0.636 \\
\hline \multicolumn{4}{|c|}{ Robust standard errors in parentheses } \\
\hline \multicolumn{4}{|c|}{ *** $p<0.01,{ }^{* *} p<0.05,{ }^{*} p<0.1$} \\
\hline
\end{tabular}

Table 2 Regression Results Source: Stata Output 
Since higher secrecy score means that the jurisdiction is less transparent, the negative result implied that increasing the secrecy level (become less transparent) would reduce profit shifting. However, it will be more useful to interpret the result in opposite way: increasing the transparency level (reducing the secrecy score) will induce profit shifting.

In the aftermath of the 2008 global financial crisis, G20 countries started the global initiative to increase transparency by forcing several jurisdictions which were considered less transparent to sign information exchange treaties under the threat of economic sanction (Johannesen \& Zucman, 2014). The effort to increase transparency was then continued by promoting the implementation of Common Reporting Standard for Automatic Exchange of Information purposes. At the same time, there is an increasing progress in the implementation of Country-by-Country Reporting for Action 13 of the BEPS. All of these ongoing projects have the sole goal to increase transparency level in combating tax evasion.

The regression result is interesting amid the global efforts to promote transparency, since it says that increasing the transparency level will induce profit shifting. However, this might have been caused by the use of data for the year 2010, 2012, and 2014, during which the global initiative in increasing transparency was still in the beginning stage and was implemented by only a handful of jurisdictions.

On an alternative view, the result shows an important finding in that transparency level is one of the determinants of profit shifting. The result implies that taxpayers located in a relatively transparent country tend to shift their money/profit out of the country. This is because they have less incentive to keep their money/profit domestically since higher transparency in the host country means a higher probability of the financial information to be exposed to tax authority.

The negative regression result should not be interpreted that jurisdiction should maintain secrecy to combat profit shifting because maintaining secrecy no longer becomes an option amid global transparency movement. The result, however, should become an alert that multilateral cooperation in promoting transparency is important. Since this paper found that ending secrecy in the host country will increase profit shifting, it is important to close the gap of incentive by implementing transparency globally. When all countries commit to end secrecy and start exchanging financial information, there will be no more incentive for taxpayers to shift their profit or money to other jurisdictions.

What about Indonesia?

The enactment of the Government Regulation in Lieu of Law Number 1 Year 2017 (hereinafter refer to Law No. 1) marks the new era of transparency in Indonesia. The Law is important in two ways. First, it becomes the legal basis for Directorate General of Taxes to access financial information for exchange of information purposes. 
Second, the law ends restriction in accessing financial information stipulated in General Provision Tax Law, Banking Law, and Sharia Banking Law.

In connection with the findings in this paper, the increase in transparency level since the enactment of the Law No. 1 provides a bigger incentive to shift money/profit out of Indonesia. Since a worldwide implementation of Automatic Exchange of Information is still in progress and several jurisdictions are yet to ratify the commitment, it is important to mitigate the increasing risk of profit shifting resulted from the ending of Indonesian banking secrecy.

Mitigating the profit shifting risk is mainly about establishing disincentive using anti-profit shifting regulations. The impacts of these regulations are well documented in empirical literature. Lohse and Riedel (2013) suggest that transfer pricing rules significantly reduce shifting activities. More precisely, they found that implementation of transfer pricing documentation reduced profit shifting by $50 \%$ on average. Blouin, Huizinga, Laeven and Nicodome (2014) found that thin capitalization rule negatively affects both total leverage and internal leverage. In addition, Markle and Robinson (2012) conclude that CFC Rules reduce the use of tax haven.

Following the end of Indonesia banking secrecy and considering the impact of the anti-profit shifting regulation, the Indonesian government then enacts Finance Minister Regulation Number PMK-169/PMK.010/2015 (thin capitalization), PMK-213/PMK.03/2016 (transfer pricing documentation) and PMK-107/PMK.03/2017 (CFC Rules). These regulations, along with the previous regulations, become an integral part in combating profit shifting by providing disincentive to evaders.

\subsection{Control Variables}

Table 2 shows that GDP per capita has a positive and significant impact on profit shifting. It says that $1 \%$ change in GDP per capita will increase profit shifting by $1.3 \%$. The finding is consistent with Baumann et. al. (2016). Furthermore, the negative coefficient of government effectiveness implies that higher government's quality is associated with lower profit shifting. Even though the coefficient is not significant, this finding still signifies the importance of government effectiveness in combating profit shifting.

The paper also measures the semi-elasticity of profit shifting. A percentage point increase of the host country's tax rate will instigate profit shifting by $6.6 \%$. Increasing the tax rate in host country will provide the taxpayers an incentive to shift their profit out of the country to minimize their tax burdens. This finding is consistent with previous findings, for example, by Hines and Rice (1994) who found an elasticity of 2.3 and Huizinga and Laeven (2008) who obtained an elasticity of 1.3 .

For the country characteristic variables, this paper found that higher occurrence of profit shifting was suffered by non-high income or developing countries and non-tax haven countries. In order to give more interpretation about country characteristic, I constructed an interaction variable of the development and the tax 
haven variables. The result can be seen in regression 3 where the interaction variable coefficient is negatively significant. This result means that the impact of the tax haven status on profit shifting depends on whether or not the country is categorized as a high income country. The impact of country status as non-tax haven on profit shifting will be greater in developing country than in developed country. Hence, the regression result for the country characteristic variables shows that profit shifting is larger in non-tax haven and low/middle income countries.

\subsection{Robustness Check}

Table 3 shows the regression results for robustness check. The table suggests that the coefficient of transparency still shows a negative and significant impact on profit shifting. The same consistent result was also found in the control variables (GDP per capita, tax rate and country characteristics). These consistent results suggest that our baseline specification is quite robust.

Table 3 Robustness Check

Source: Stata Output

\begin{tabular}{|c|c|c|}
\hline & (1) & (2) \\
\hline VARIABLES & Itmo & Itmo \\
\hline \multirow[t]{2}{*}{ ss } & $-0.126^{\star \star \star}$ & $-0.0425^{\star \star}$ \\
\hline & $(0.0151)$ & $(0.018)$ \\
\hline \multirow[t]{2}{*}{ Igdppc } & & $1.658^{\star \star \star}$ \\
\hline & & $(0.372)$ \\
\hline \multirow[t]{2}{*}{ govqual } & & $-0.963^{\star \star}$ \\
\hline & & $(0.459)$ \\
\hline \multirow[t]{2}{*}{ taxrate } & & $0.0774^{\star \star \star}$ \\
\hline & & $(0.0237)$ \\
\hline \multirow[t]{2}{*}{ high } & & $-1.203^{\star \star}$ \\
\hline & & $(0.581)$ \\
\hline \multirow[t]{2}{*}{ nonhaven } & & $2.146^{\star \star \star}$ \\
\hline & & $(0.666)$ \\
\hline \multirow[t]{2}{*}{ Constant } & $15.08^{\star \star \star}$ & $-7.157^{\star}$ \\
\hline & $(1.081)$ & (3.705) \\
\hline Observations & 79 & 66 \\
\hline R-squared & 0.414 & 0.667 \\
\hline \multicolumn{3}{|c|}{ Robust standard errors in parentheses } \\
\hline${ }^{* * *} p<0.01,{ }^{* *} p<0.05,{ }^{*} p<0.1$ & & \\
\hline
\end{tabular}




\section{CONCLUSIONS AND RECOMMENDATIONS}

The roles of financial secrecy on profit shifting are not well documented in literature. This paper, to my knowledge, provides the first empirical result on the impact of financial secrecy on profit shifting. This paper also uses the illicit financial outflows as a new proxy for profit shifting instead of the accounting profit which was widely used in previous literature.

The result suggests that the secrecy negatively affects profit shifting. This means that an effort to increase transparency will induce the taxpayers to shift profit out of the country. As the transparency in a host country improves, the risk of tax authority accessing financial information also heightens. Therefore, there is a higher incentive for taxpayers to shift their money/profit out of the country.

From the perspective of tax authority, the result implies two important recommendations. First, the tax authorities should continue the global efforts to promote the exchange of financial information for tax purposes, providing disincentive for tax evaders so that there will be no more place to hide away their wealth. Second, anticipating that there will still be some jurisdictions which do not join the information exchange framework, anti-profit shifting domestic regulations should be established and strengthened. To summarize, these recommendations basically build the disincentive for tax evaders.
Regarding the control variables, this paper finds several compelling findings. The measurement of semi-elasticity of profit shifting resulting in 6.6 means that a percentage-point increase in tax rate will increase profit shifting by $6.6 \%$. As regards the country characteristics variable, it is evidenced that profit shifting is larger in non-tax haven and low/middle income countries.

\section{REFERENCES}

[1] Akhtar, S., Akhtar, F., John, K., \& Wong, S. (2017). Multinationals' Tax Evasion: A Financial and Governance Perspective. Journal of Corporate Finance. Retrieved from https://doi.org/10.1016/j.jcorpfin.2017.11.009

[2] Arnold, B.J., \& McIntyre, M.J. (2002). International Tax Primer. The Netherland: Kluwer Law International.

[3] Baumann, F., Buchwald, A., Friehe, T., Hottenrott, H., \& Weche, J. (2016). Tax Enforcement and Corporate Profit Shifting. Applied Economics Letters, 24(13), 902-905.

[4] Beer, S., de Mooij, R., \& Liu, L. (2018). International Corporate Tax Avoidance: A Review of The Channels, Effect Sizes, and Blind Spots (IMF Working Paper WP/18/168). Washington DC: IMF.

[5] Blouin, J., Huizinga, H., Laeven, L., \& Nicodome, G. (2014). Thin Capitalization Rules and Multinational Firm Capital Structure (IMF Working Paper WP/14/12). Washington DC: IMF.

[6] Buettner, T., Overesch, M., \& Wamser, G. (2017). Anti Profit-Shifting Rules and Foreign Direct Investment. International Tax and Public Finance, 25(3), 553-580.

[7] Chernykh, L., \& Mityakov, S. (2017). Offshore Schemes and Tax Evasion: The Role of Banks. Journal of Financial Economics, 126(3), 516-542.

[8] Clausing, K.A. (2016). The Effect of Profit Shifting on The Corporate Tax Base in the United States and Beyond. National Tax Journal, 69(4), 905-934. 
9] Cobham, A., Jansky, P., \& Meinzer, M. (2015). The Financial Secrecy Index: Shedding New Light on the Geography of Secrecy. Economic Geography, 91(3), 281-303.

[10] Crivelli E., de Mooij, R., \& Keen, M. (2015). Base Erosion, Profit Shifting and Developing Countries (IMF Working Paper WP/15/118). Washington DC: IMF.

[11] Dharmapala, D., \& Hines, J.R. (2009). Which Countries Become Tax Havens?. Journal of Public Economics, 93, 1058-1068.

[12] Dharmapala, D., \& Riedel, N. (2013). Earning Shocks and Tax-Motivated Income Shifting: Evidence from European Multinationals. Journal of Public Economics, 97, 95-107.

[13] Dyreng, S. D., \& Lindsey, B. P. (2009). Using Financial Accounting Data to Examine the Effect of Foreign Operations Located in Tax Havens and Other Countries on U.S. Multinational Firms' Tax Rates. Journal of Accounting Research, 47(5), 1283-1316.

[14] Foad, H., \& Lundberg, C. (2017). The Determinants of Portfolio Investment in Offshore Financial Centers. International Review of Financial Analysis, 54, 76-86.

[15] Global Financial Integrity. (2017). Illicit Financial Flows to and from Developing Countries. Retrieved from https://www.gfintegrity.org/wp-content/uploads/2017/05/G FI-IFF-Report-2017_final.pdf

[16] Grubert, H., \& Mutti, J. (1991). Taxes, Tariffs and Transfer Pricing in Multinational Corporate Decision Making. The Review of Economics and Statistics, 73(2), 285-293.

[17] Hansen, N.A, \& Kessler, A.S. (2001). The Political Geography of Tax H(e)avens and Tax Hells. American Economic Review, 91(4), 1103-1115.

[18] Heckemeyer, J.H., \& Overesch, M. (2017). Multinationals' Profit Response to Tax Differentials: Effect Size and Shifting Channels. Canadian Journal of Economics, 50(4), 965-994.

[19] Hines Jr., J.R., \& Rice, E.M. (1994). Fiscal Paradise: Foreign Tax Havens and American Business. Quarterly Journal of Economics, 109, 149-82.
[20] Huizinga, H., \& Laeven, L. (2008). International Profit Shifting Within Multinationals: A Multi-Country Perspective. Journal of Public Economics, 92, 1164-1182.

[21] Jansky, P., \& Prats, A. (2015). International Profit Shifting out of Developing Countries and The Role of Tax Havens. Development Policy Review, 33(3), 271-292.

[22] Johannesen, N., \& Zucman, G. (2014). The End of Bank Secrecy? An Evaluation of the G20 Tax Haven Crackdown. American Economic Journal: Economic Policy, 6(1), 65-91.

[23] Kaufmann, D., Kraay, A., \& Mastruzzi, M. (2005). Governance Matters IV: Governance Indicators for 1996-2994 (World Bank Working Paper)

[24] Lohse, T., \& Riedel, N. (2013). Do Transfer Pricing Laws Limit International Profit Shifting? Evidence from European Multinationals (CESifo Working Paper No. 4404).

[25] Maffini, G., \& Mokkas, S. (2011). Profit Shifting and Measured Productivity of Multinational Firms. Oxford Bulletin of Economics and Statistics, 73, 0305-9049.

[26] Mara, E.R. (2015). Determinants of Tax Havens. Procedia Economics and Finance, 32, $1638-1646$.

[27] Markle, K., \& Robinson, L. (2012). Tax Haven Use Across International Tax Regimes. Mimeo, University of Waterloo and Dartmouth College.

[28] Murphy, R. (2008). Finding the Secrecy World: Rethinking the Language of "offshore". London: Tax Research LLP. Retrieved October 17, 2018 from http://www.taxresearch.org.uk/Documents/Finding.pdf

[28] OECD. (1998). Harmful Tax Competition: An Emerging Global Issue. Paris: OECD.

[29] OECD. (2015). 2015 Final Reports, OECD/G20 Base Erosion and Profit Shifting Project. Paris: OECD Publishing.

[30] OECD. (2015a). Measuring and Monitoring BEPS, Action 11-Final Report. Paris: OECD Publishing.

[31] OECD. (2018). Glossary of Tax Term. Available at http://www.oecd.org/ctp/glossaryoftaxterms.htm\#P

[32] Picard, P.M., \& Pieretti, P. (2011). Bank Secrecy, Illicit Money and Offshore Financial Centers. Journal of Public Economics, 95, 942-955. 
[33] Rose, A.K., \& Spiegel, M.M. (2007). Offshore Financial Centres: Parasite or Symbionts?. The Economic Journal, 117, 1310-1335.

[34] Tax Justice Network. (2015). Financial Secrecy Index 2015: Methodology. Retrieved from

https://www.financialsecrecyindex.com/Archive2015/Notes\%20and\%20Reports/FSIMethodology.pdf
[35] Torslov, T.R., Wier, L.S., \& Zucman, G. (2018). The Missing Profits of Nations (NBER Working Paper 24701). Cambridge: National Bureau of Economic Research.

[36] United Nation. (2017). Practical Manual on Transfer Pricing for Developing Countries. New York: United Nations.

\section{APPENDIX}

\section{Variable Definition}

\begin{tabular}{|c|c|c|}
\hline Symbol & Variable & Source \\
\hline liffo & $\begin{array}{l}\text { Illicit Financial Outflow } \\
\text { (natural log) }\end{array}$ & \multirow[t]{2}{*}{$\begin{array}{l}\text { Global Financial Integrity: https://www.gfintegrity.org/wp- } \\
\text { content/uploads/2017/04/IFF_2017-04_WebTables.xlsx }\end{array}$} \\
\hline Itmo & $\begin{array}{l}\text { Trade Misinvoicing } \\
\text { Outflow (natural log) }\end{array}$ & \\
\hline \multirow[t]{4}{*}{ ss } & \multirow[t]{4}{*}{ Secrecy Score } & Tax Justice Network: \\
\hline & & $\begin{array}{l}\text { https://www.financialsecrecyindex.com/Archive2015/Notes\%20and\%20Reports/FSI } \\
\text {-Rankings-2015.xlsx }\end{array}$ \\
\hline & & $\begin{array}{l}\text { https://www.financialsecrecyindex.com/Archive2013/Notes\%20and\%20Reports/FSI } \\
\text {-Rankings-2013.xlsx }\end{array}$ \\
\hline & & $\begin{array}{l}\text { https://www.financialsecrecyindex.com/Archive2011/FSI-2011/FSI-Rankings- } \\
\text { 2011.xls }\end{array}$ \\
\hline Igdppc & $\begin{array}{l}\text { GDP per capita } \\
\text { (natural log) }\end{array}$ & World Bank: http://databank.worldbank.org/data/download/WDI_excel.zip \\
\hline goveff & $\begin{array}{l}\text { Government } \\
\text { Effectiveness }\end{array}$ & \multirow[t]{2}{*}{$\begin{array}{l}\text { The Worldwide Governance Indicators: } \\
\text { http://info.worldbank.org/governance/wgi/wgidataset.xlsx }\end{array}$} \\
\hline govqual & Government Quality & \\
\hline taxrate & Statutory Tax Rate & KPMG \\
\hline high & $\begin{array}{l}\text { Developed/High } \\
\text { Income Country }(=1)\end{array}$ & World Bank: http://databank.worldbank.org/data/download/site-content/CLASS.xls \\
\hline nonhaven & $\begin{array}{l}\text { Non-Tax Haven } \\
\text { Country }(=1)\end{array}$ & Hines and Rice (1994) \\
\hline
\end{tabular}

